\title{
Comments on a systematic review and meta-analysis of steroids for epidural injections in spinal stenosis
}

Laxmaiah Manchikanti ${ }^{1,2}$

Joshua A Hirsch ${ }^{3,4}$

'Pain Management Center of Paducah, Paducah, KY, USA; ${ }^{2}$ Anesthesiology and Perioperative Medicine, University of Louisville, Louisville, KY, USA; ${ }^{3}$ Interventional Care, Minimally Invasive Spine Surgery, Interventional Radiology, Neurolnterventional Services and Neuroendovascular Program, Massachusetts General Hospital, Boston, MA, USA;

${ }^{4}$ Department of Radiology, Harvard Medical School, Boston, MA, USA
Correspondence: Laxmaiah Manchikanti Pain Management Center of Paducah Medical Director, 283I Lone Oak Road, Paducah, KY 42003, USA

Emaildrlm@thepainmd.com
This article was published in the following Dove Press journal:

Drug Design, Development and Therapy

20 May 2015

Number of times this article has been viewed

\section{Dear editor}

We read with interest the manuscript by Liu et al ${ }^{1}$ a systematic review and meta-analysis of steroids for epidural injection in spinal stenosis. The results showed there was fair short- and long-term benefit for treating spinal stenosis with local anesthetic and steroids; however, the authors concluded that the meta-analysis suggested that epidural steroid injections provided limited improvement in short- and long-term benefits in lumbar spinal stenosis patients. This may be confusing to the readership. Fair evidence essentially provides moderate benefits, but the conclusion shows limited improvement.

Further, the authors included a wide variety of studies which are not applicable to the meta-analysis. Issues include studies performed with or without fluoroscopy, with short-term and long-term follow-up, with local anesthetic or without local anesthetic, inter-laminar, caudal, and transforaminal approaches, and some very small studies. Multiple studies with variable bias were also included in the meta-analysis. Further, the risk of bias assessment appears to be inappropriate. For example, both studies by Manchikanti et al, ${ }^{2,3}$ even though identical, were rated differently showing variable bias. Further, multiple items were rated inaccurately which differed for each study even though they were identical. These two trials have been assessed in the past in multiple systematic reviews ${ }^{4-7}$ and were rated as high quality, meeting at least 8 of 12 criteria of Cochrane review criteria which have been compressed to 7 in this assessment with one trial ${ }^{3}$ scoring 4 of 7 and the second trial ${ }^{2}$ scoring 3 of 7 instead of both trials scoring 6 of 7 . Further, the highly rated trial by Friedly et al, ${ }^{8}$ which has generated significant attention, has been met with criticism for its flawed analysis and extremely short follow-up period. ${ }^{9}$

We compliment Dr Liu et al on their effort. The analysis would be improved by better focus on appropriate inclusion criteria and precision in the establishment of criteria for homogeneity. Finally, appropriate methodologic quality or risk of bias are essential to reach unbiased clinically relevant conclusions. ${ }^{47,9,10}$

\section{Disclosure}

Dr Manchikanti has provided limited consulting services to Semnur Pharmaceuticals, Incorporated, which is developing non-particulate steroids. Dr Hirsch is a consultant for Medtronic. 


\section{References}

1. Liu K, Liu P, Liu R, Wu X, Cai M. Steroid for epidural injection in spinal stenosis: a systematic review and meta-analysis. Drug Des Devel Ther. 2015;9:707-716.

2. Manchikanti L, Cash KA, McManus CD, Pampati V, Fellows B. Results of 2-year follow-up of a randomized, double-blind, controlled trial of fluoroscopic caudal epidural injections in central spinal stenosis. Pain Physician. 2012;15(5):371-384.

3. Manchikanti L, Cash KA, McManus CD, et al. Lumbar interlaminar epidural injections in central spinal stenosis: Preliminary results of a randomized, double-blind, active control trial. Pain Physician. 2012;15(1):51-63.

4. Parr AT, Manchikanti L, Hameed H, et al. Caudal epidural injections in the management of chronic low back pain: A systematic appraisal of the literature. Pain Physician. 2012;15(3):E159-E198.

5. Benyamin RM, Manchikanti L, Parr AT, et al. The effectiveness of lumbar interlaminar epidural injections in managing chronic low back and lower extremity pain. Pain Physician. 2012;15(4): E363-E404.
6. Manchikanti L, Nampiaparampil DE, Manchikanti KN, et al. Comparison of the efficacy of saline, local anesthetics, and steroids in epidural and facet joint injections for the management of spinal pain: A systematic review of randomized controlled trials. Surg Neurol Int. 2015;6:S194-S235.

7. Manchikanti L, Kaye AD, Manchikanti KN, Boswell MV, Pampati V, Hirsch JA. Efficacy of epidural injections in the treatment of lumbar central spinal stenosis: A systematic review. Anesth Pain Med. 2015;5(1):e23139.

8. Friedly JL, Comstock BA, Turner JA, et al. A randomized trial of epidural glucocorticoid injections for spinal stenosis. $N$ Engl J Med. 2014;371(1):11-21.

9. Manchikanti L, Candido KD, Kaye AD, et al. Randomized trial of epidural injections for spinal stenosis published in the New England Journal of Medicine: Further confusion without clarification. Pain Physician. 2014;17(4):E475-E488.

10. Manchikanti L, Benyamin RM, Falco FJ, Kaye AD, Hirsch JA. Do epidural injections provide short- and long-term relief for lumbar disc herniation? A systematic review. Clin Orthop Relat Res. 2015;473:1940-1956. 


\section{Authors' reply \\ Pengcheng Liu \\ Xing Wu}

Department of Orthopaedics, Shanghai Tenth People's Hospital, Tongji University, School of Medicine, Shanghai, People's Republic of China

Correspondence: Xing Wu

30I Middle Yanchang Road, Shanghai Tenth People's Hospital, Shanghai, 200072, People's Republic of China

Email orthopedics_dsyy@I26.com

\section{Dear editor}

Although we recognize the limitations of our meta-analysis, as noted by Dr Manchikanti, we included a wide variety of studies which may not be applicable to the meta-analysis, which are associated with issues including studies performed with or without fluoroscopy, with short-term and long-term follow-up, with local anesthetic or without local anesthetic, inter-laminar, caudal, and transforaminal approaches, and some very small studies, and some studies with variable bias were also included in the meta-analysis. We argue that we included randomized controlled trials that evaluated the efficacy and safety of epidural injections of steroids plus local anesthetic versus local anesthetic alone for the treatment of lumbar spinal stenosis (LSS) patients. ${ }^{1}$ The inclusion criteria for the systematic review and meta-analysis were as follows: 1) randomized controlled trials in adults with LSS with epidural injection treatment; 2) clinical or radiological diagnosis of LSS; 3) describe neurogenic claudication with back (leg) pain and gait assessment; 4) provide the dosage and route of epidural steroid injection administration; and 5) outcomes measured, such as walking ability, pain intensity, quality of life, and global improvement. Studies evaluating radiculopathy caused by disc lesions were excluded. Studies with mixed populations were only included if the data for neurogenic claudication due to LSS were provided. ${ }^{1}$

The comments by Manchikanti and Hirsch are also important to consider. However, we wish to clarify several points. First, assessment of the methodological quality was performed independently by two investigators, the methodological quality of the trials was assessed using the Cochrane Handbook for Systematic Reviews of Interventions 5.1.0. These two trials by Manchikanti et $\mathrm{al}^{2,3}$ scoring lower scores than assessment by themselves may be caused by a hidden information source that we do not know about. Second, as noted by Manchikanti et al, ${ }^{4}$ the trial by Friedly et $\mathrm{al}^{5}$ which has generated significant attention in our meta-analysis has been met with criticism for its flawed analysis and extremely short follow-up period. We also recognized some limitations of this trial such as acute pain patients being included, and that multilevel stenosis and various other factors were not identified and may have caused the risk of bias. Third, we also mentioned that in 2013, North America Spine Society's Evidence-Based Clinical Guideline Development Committee developed an evidence-based clinical guideline ${ }^{6}$ for the diagnosis and treatment of degenerative LSS. They found evidence supporting the recommendation of epidural steroid injection therapy, elaborating a B recommendation in favor of it use. However, this systematic review was based on only four $^{7-10}$ trials. As Manchikanti and Hirsch point out, appropriate methodologic quality or risk of bias are essential to reach unbiased clinically relevant conclusions. We compliment Dr Manchikanti and Dr Hirsch on their effort. Finally, additional better and rigorous studies with long-term observation are required to elucidate the effectiveness of epidural steroid injection treatment for LSS. ${ }^{1}$

\section{Disclosure}

The authors report no conflicts of interest in this communication.

\section{References}

1. Liu K, Liu P, Liu R, Wu X, Cai M. Steroid for epidural injection in spinal stenosis: a systematic review and meta-analysis. Drug Des Devel Ther. 2015;9:707-716.

2. Manchikanti L, Cash KA, McManus CD, Pampati V, Fellows B. Results of 2-year follow-up of a randomized, double-blind, controlled trial of fluoroscopic caudal epidural injections in central spinal stenosis. Pain Physician. 2012;15(5):371-384.

3. Manchikanti L, Cash KA, McManus CD, et al. Lumbar interlaminar epidural injections in central spinal stenosis: preliminary results of a randomized, double-blind, active control trial. Pain Physician. 2012;15(1): $51-63$.

4. Manchikanti L, Candido KD, Kaye AD, et al. Randomized trial of epidural injections for spinal stenosis published in the New England Journal of Medicine: Further confusion without clarification. Pain Physician. 2014;17(4):E475-E488.

5. Friedly JL, Comstock BA, Turner JA, et al. A randomized trial of epidural glucocorticoid injections for spinal stenosis. $N$ Engl J Med. 2014;371(1):11-21.

6. Kreiner DS, Shaffer WO, Baisden JL, et al. An evidence-based clinical guideline for the diagnosis and treatment of degenerative lumbar spinal stenosis (update). Spine J. 2013;13(7):734-743.

7. Cuckler JM, Bernini PA, Wiesel SW, et al. The use of epidural steroids in the treatment of lumbar radicular pain. A prospective, randomized, double-blind study. J Bone Joint Surg Am. 1985;67(1):63-66.

8. Fukusaki M, Kobayashi I, Hara T, Sumikawa K. Symptoms of spinal stenosis do not improve after epidural steroid injection. Clin J Pain. 1998;14(2):148-151.

9. Koc Z, Ozcakir S, Sivrioglu K, Gurbet A, Kucukoglu S. Effectiveness of physical therapy and epidural steroid injections in lumbar spinal stenosis. Spine (Phila Pa 1976). 2009;34(10):985-989.

10. Papagelopoulos PJ, Petrou HG, Triantafyllidis PG, et al. Treatment of lumbosacral radicular pain with epidural steroid injections. Orthopedics. 2001;24(2):145-149. 
Dove Medical Press encourages responsible, free and frank academic debate. The content of the Drug Design, Development and Therapy 'letters to the editor' section does not necessarily represent the views of Dove Medical Press, its officers, agents, employees, related entities or the Drug Design, Development and Therapy editors. While all reasonable steps have been taken to confirm the content of each letter, Dove Medical Press accepts no liability in respect of the content of any letter, nor is it responsible for the content and accuracy of any letter to the editor.

Drug Design, Development and Therapy

\section{Dovepress}

\section{Publish your work in this journal}

Drug Design, Development and Therapy is an international, peerreviewed open-access journal that spans the spectrum of drug design and development through to clinical applications. Clinical outcomes, patient safety, and programs for the development and effective, safe, and sustained use of medicines are a feature of the journal, which

has also been accepted for indexing on PubMed Central. The manuscript management system is completely online and includes a very quick and fair peer-review system, which is all easy to use. Visit http://www.dovepress.com/testimonials.php to read real quotes from published authors.

Submit your manuscript here: http://www.dovepress.com/drug-design-development-and-therapy-journal 